\title{
In-vitro antioxidant activity and nutritional value of four wild oyster mushroom collected from North-Eastern Part of Uttar Pradesh
}

\author{
Vishwakarma $\mathbf{P}^{1 *}$, Singh $\mathbf{P}^{1}$ and Tripathi $\mathrm{NN}^{1}$ \\ ${ }^{I}$ Bacteriology and Natural Pesticide Laboratory, Department of Botany, DDU Gorakhpur University, Gorakhpur, \\ 273009, U.P. (India)
}

Vishwakarma P, Singh P and Tripathi NN 2017 - In-vitro antioxidant activity and nutritional value of four wild oyster mushroom collected from North-Eastern Part of Uttar Pradesh. Mycosphere 8(4), 592-602, Doi 10.5943/mycosphere/8/4/8

\begin{abstract}
Four species of wild edible oyster mushroom viz., Pleurotus cystidiosus OK. Mill., $P$. flabellatus (Berk \& Br.) Sacc., P. florida (Mont.) Singer and P. ostreatus (Jacq: Fries) were selected to evaluate their antioxidant property and bioactive compounds ( $\beta$-carotene, lycopene, ascorbic acid and phenolic content). The antioxidant property of all tested mushroom extracts gave a positive result with free radical scavenging potentials. Phenolic content ranged from 37.70-39.01 $\mathrm{mg} / \mathrm{g}$. P. ostreatus showed highest antioxidant activity in all tested protocols (DPPH: $0.1884 \mathrm{mg} / \mathrm{ml}$, $\beta$-carotene bleaching assay: $0.362 \mathrm{mg} / \mathrm{ml}, \mathrm{H}_{2} \mathrm{O}_{2}$ Scavenging assay: $0.820 \mathrm{mg} / \mathrm{ml}$ ) in comparison to other three species tested viz., $P$. cystidiosus, $P$. flabellatus and $P$. florida. All mushroom tested exhibited significant antioxidant properties which therefore can be promoted as natural antioxidant preference in food and can also be used as nutraceuticals.
\end{abstract}

Key words - bioactive compounds - biochemical - DPPH - phenol - Pleurotus

\section{Introduction}

Oxidation is essential for every living organism for the production of energy to fuel biological processes. However, the uncontrolled production of oxygen derived free radicals is involved in the onset of many diseases such as cancer, rheumatoid arthritis and atherosclerosis as well as in degenerative processes associated with aging (Turkoglu et al. 2006). Organisms are protected against free radical damage by enzyme such as superoxide dismutase and catalase or compounds such as ascorbic acid, tocopherols and glutathione (Mau et al. 2002). Mushrooms belonging to different taxa occupying diverse ecological niches have shown various degrees of antioxidant potentials. It contains various bioactive compounds such as phenolic compounds, polyketides, terpenes and steroids which are recognized as excellent antioxidants (Orsine et al. 2012). Antioxidant activity of mushroom shows strong inhibition of lipid peroxidation at high concentration of the extracts in most cases (Cheung \& Peter 2005). Antioxidant activity of mushrooms includes scavenging of free radicals through hydrogen holding capacity and oxidation by peroxy radicals (Chang et al. 2007). Oyster mushrooms are preferred by many people for its taste, texture and unique aroma (Arbaayah \& Umi 2013), belong to class Basidiomycetes and family Agariaceae. It is an edible mushroom and grows on logs and tree stumps in shelf like pattern (Johnsy \& Okon 2013) in tropical and subtropical areas and also cultivated easily (Chirinang \& Intarapichet 2009). Oyster mushrooms are good source of non-starchy carbohydrates, dietary fibre 
and good quantity of proteins which include most of amino acids, minerals and vitamins (Ahmed et al. 2013). Fruiting body of Pleurotus possesses higher concentration of antioxidants than other commercial mushrooms (Patel et al. 2012, Roy \& Prasad 2013). This property is due to the presence of pleuran (glucan) a polysaccharide isolated from P. ostreatus (Atri et al. 2012).

The aim of this study was to evaluate the antioxidant activity and nutritive value of four wild oyster mushroom collected from Gorakhpur forest regions.

\section{Materials \& Methods}

\section{Sample collection, identification $\&$ processing}

Samples of four oyster mushrooms viz., Pleurotus cystidiosus, P.flabellatus, P. florida, P. ostreatus were collected from forest regions of Gorakhpur during the months of July to August 2011-2013. Collected samples were identified on the basis of their macro and microscopic characterization following Kong (2004) and Atri et al. (2012). Samples were cleaned and dried in shadow at room temperature for 14 days. It was then grinded to make fine powder with the help of grinder and stored for further study.

\section{Evaluation of antioxidant property}

Following methods were used to evaluate the antioxidant activity of oyster mushroom.

\section{DPPH (2, 2'- diphenyl-1-picrylhydazyl) radical scavenging bioassay}

During the bioassay, a stock solution of mushroom was prepared by taking $10 \mathrm{~g}$ fresh sample with $100 \mathrm{ml}$ of $70 \%$ ethanol following Barros et al. (2008) and the prepared extract was filtered through Whatmann No. 1 filter paper. Different concentrations $(1,2,3,4 \& 5 \mathrm{mg} / \mathrm{ml})$ of 1 $\mathrm{ml}$ of prepared stock solution mushroom were mixed with $1 \mathrm{ml}$ methanolic solution of $0.2 \mathrm{mM}$ DPPH radicals separately. The mixture was shaken vigorously and left to stand for $60 \mathrm{~min}$ in the dark (until stable absorption values were obtained). The reduction of the DPPH radical was determined by measuring the absorption at $517 \mathrm{~nm}$ by spectrophotometer (U-2900 UV/VIS, Model No. 2J1-004, Japan). The radical scavenging activity (RSA) was calculated as a percentage of DPPH discoloration using the equation:

$$
\operatorname{RSA}(\%)=\left[\left(\mathrm{A}_{0}-\mathrm{As}\right) / \mathrm{A}_{0}\right] \times 100
$$

where $A_{0}$ is the absorbance of control and As is the absorbance of the tested sample. The extract concentration providing $50 \%$ of radicals scavenging activity $\left(\mathrm{EC}_{50}\right)$ was calculated from the graph of RSA percentage against extract concentration.

\section{Inhibition of $\beta$-carotene bleaching}

The antioxidant activity of fresh mushroom extract was evaluated following Barros et al. (2008) using $\beta$-carotene linoleate model system. A solution of $\beta$-carotene was prepared by dissolving $\beta$-carotene $(2 \mathrm{mg})$ in chloroform $(10 \mathrm{ml})$. Two milliliters of this solution were taken into a $100-\mathrm{ml}$ flask. After the chloroform was removed at $40{ }^{\circ} \mathrm{C}$ under vacuum, linoleic acid $(40 \mathrm{mg})$, Tween 80 emulsifier $(400 \mathrm{mg})$, and distilled water $(100 \mathrm{ml})$ were added to the flask with vigorous shaking. Aliquots $(4.8 \mathrm{ml})$ of this emulsion were transferred into different test tubes containing 0.2 $\mathrm{ml}$ of different concentrations $(1,2,3,4, \& 5 \mathrm{mg} / \mathrm{ml})$ of the mushroom extracts. The tubes were shaken and incubated at $50{ }^{\circ} \mathrm{C}$ in a water bath. As soon as the emulsion was added to each tube, the zero-time absorbance was measured at $470 \mathrm{~nm}$ using a spectrophotometer (U-2900 UV/VIS, Model No. 2J1-004, Japan). Absorbance readings were then recorded at 20-min intervals until the control sample had changed colour. A blank, devoid of $\beta$-carotene, was prepared for background subtraction. Lipid peroxidation (LPO) inhibition was calculated using the following equation:

$$
\text { LPO inhibition }=\frac{\beta-\text { carotene content after } 2 \mathrm{~h} \text { of assay }}{\text { initial } \beta \text {-carotene content }} \mathrm{X} 100
$$

The extract concentration providing $50 \%$ antioxidant activity $\left(\mathrm{EC}_{50}\right)$ was calculated from the graph of antioxidant activity percentage against extract concentration. 
Hydrogen peroxide $\left(\mathrm{H}_{2} \mathrm{O}_{2}\right)$ radical scavenging activity

For estimation of $\mathrm{H}_{2} \mathrm{O}_{2}$ scavenging activity, method of Vamanu (2012) was used. In this process $\mathrm{H}_{2} \mathrm{O}_{2}$ solution $(40 \mu \mathrm{M})$ was prepared in phosphate buffer $(50 \mathrm{mM}$, pH 7.4). Extract of different concentration $(1,2,3,4,5 \mathrm{mg} / \mathrm{ml})$ were mixed with $\mathrm{H}_{2} \mathrm{O}_{2}$ solution $(0.6 \mathrm{ml})$ and absorbance of sample were observed at $230 \mathrm{~nm}$ after $10 \mathrm{~min}$ against blank solution (phosphate buffer without $\mathrm{H}_{2} \mathrm{O}_{2}$ ).

\section{Bioactive compounds}

Following methods were used to evaluate the bioactive compounds of oyster mushroom.

$\beta$ - carotene and Lycopene

$\beta$ - carotene and lycopene were determined by the method described by Loganathan et al. (2009). About $100 \mathrm{mg}$ of dried ethanolic extract was vigorously shaken for $1 \mathrm{~min}$ with acetone and hexane $(4: 6 \mathrm{v} / \mathrm{v})$ mixture making final volume of $10 \mathrm{ml}$ and filtered through Whatmann No. 1 filter paper. The absorbance of the filtrate was measured at $\lambda=453,505$ and $663 \mathrm{~nm}$. Contents of $\beta$ carotene and lycopene were calculated according to the following equations:

Lycopene $(\mathrm{mg} / 100 \mathrm{ml})=0.0458 \mathrm{~A} 663+0.372 \mathrm{~A} 505-0.0806 \mathrm{~A} 453$

$\beta$ - carotene $(\mathrm{mg} / 100 \mathrm{ml})=0.216 \mathrm{~A} 663-0.304 \mathrm{~A} 505+0.452 \mathrm{~A} 453$

The results were expressed as $\mu \mathrm{g}$ of carotenoid/g of extract.

\section{Ascorbic acid}

The vitamin $C$ content was determined titrametrically using 2, 6 Dichloropheno Indophenol method following Barros et al. (2008). $10 \mathrm{~g}$ of grounded sample was mixed with $100 \mathrm{ml}$ of 5\% metaphosphoric acid solution and shaken for $30 \mathrm{~min}$. The mixture was then filtered through Whtaman no 1 filter paper. $10 \mathrm{ml}$ of test sample was pippeted from the extract in $250 \mathrm{ml}$ conical flask and titrated against $0.025 \%$ of 2.6 Dichlorophenol Indophenol reagents. The amount of vitamin $\mathrm{C}$ in each extract was calculated from the equation:

$$
\text { Per cent of ascorbic acid }=\frac{\text { titre } \mathrm{x} \text { Dye factor } \mathrm{x} \text { volume made }}{\text { Aliquot of extract } \mathrm{x} \text { weight }} X 100
$$

Phenolic content

Phenolic compounds in the ethanol extracts were determined using Folin-Ciocalteu method (Loganathan et al. 2010). One $\mathrm{ml}$ of the extract was added to $10.0 \mathrm{ml}$ distilled water and $2.0 \mathrm{ml}$ of Folin-Ciocalteu reagent. The mixture was allowed to stand at room temperature for $5 \mathrm{~min}$ and then $2.0 \mathrm{ml}$ of $20 \%$ sodium carbonate was added to the mixture. The resulting blue complex was then measured at $680 \mathrm{~nm}$. Gallic acid was used as a standard for the calibration curve. The phenol compound was calibrated using the linear equation based on the calibration curve. The contents of the phenolic compound were expressed as $\mathrm{mg}$ Gallic acid equivalent/g dry weight.

\section{Biochemical assay}

Moisture content was determined following Oyetayo et al. (2007). Protein content of macrofungal samples were determined by the method of Lowry et al. (1951), carbohydrate was estimated by Anthrone method of Thimmaiah (1999). Crude fibre content was evaluated following Alam et al. (2008) while lipid was estimated by the method of Folch et al. (1957). Ash of the sample was estimated by the method of Pearson (1976).

\section{Statistical Analysis}

Experimental values are given as mean \pm standard deviation (SD). Statistical significance was determined by one way variance analysis (ANOVA). Difference at $p<0.05$ were considered to be significant. 


\section{Results}

\section{Characteristics of oyster mushroom collected}

Table 1 represents the morphological characterization of collected oyster mushrooms. Their spore prints and substrate were also recorded.

Table 1 Habit, habitat and morphology of collected oyster mushrooms

\begin{tabular}{|c|c|c|c|c|c|}
\hline Mushrooms & Locality & Host & Fruiting body & $\begin{array}{l}\text { Colleciotion } \\
\text { Date }\end{array}$ & Voucher no. \\
\hline $\begin{array}{l}\text { P. cystidiosus } \\
\text { OK. Mill. }\end{array}$ & Gagaha & $\begin{array}{l}\text { Ficus } \\
\text { benghalensis }\end{array}$ & $\begin{array}{l}\text { Pileus } 4-6 \mathrm{~cm} \text {, smooth, grayish } \\
\text { brown, convex, then flattened, } \\
\text { margin smooth, narrowing at } \\
\text { point of attachment. Stipe } 1-2 \\
\mathrm{~cm} \text { grayish brown, smooth, } \\
\text { eccentric, very short, wooly, } \\
\text { stout, ring absent. Gills } \\
\text { decurrent, at first white, } \\
\text { becoming tinged, pallid, } \\
\text { ochraceous, narrow, close. } \\
\text { Spores 8-10 X 4-5.5 } \mu \mathrm{m} \text {, } \\
\text { ellipsoid, hyaline, smooth, non- } \\
\text { amyloid. Flesh white, firm and } \\
\text { full. Spore print creamish. }\end{array}$ & $21 / 7 / 13$ & DDUNPL246 \\
\hline $\begin{array}{l}\text { P. flabellatus } \\
\text { (Berk \& Br.) } \\
\text { Sacc. }\end{array}$ & Piprauli & $\begin{array}{l}\text { Decaying } \\
\text { wood }\end{array}$ & $\begin{array}{l}\text { Pileus } 3-7 \mathrm{~cm} \text {, creamish white, } \\
\text { surface smooth, thin, margin } \\
\text { wavy, curved, narrowing at point } \\
\text { of attachment with stipe. Stipe } \\
0.5-1 \mathrm{~cm} \text {, creamish white, } \\
\text { smooth, eccentric, very short, } \\
\text { stout, ring absent. Gills } \\
\text { decurrent, creamish, narrow, } \\
\text { close. Spores } 7.5-8 \times 2.5-4 \mu \mathrm{m} \text {, } \\
\text { ellipsoid, smooth, hyaline, non- } \\
\text { amyloid. Flesh white, firm, full. } \\
\text { Spore print white. }\end{array}$ & $24 / 6 / 13$ & DDUNPL248 \\
\hline $\begin{array}{l}P . \quad \text { florida } \\
\text { (Mont.) Singer }\end{array}$ & Khajni & $\begin{array}{l}\text { Ficus } \\
\text { religiosa }\end{array}$ & $\begin{array}{l}\text { Pileus } 5-8 \mathrm{~cm} \text {, pale yellow, } \\
\text { smooth, thick, leathery, margin } \\
\text { wavy, flattened, narrowing at } \\
\text { point of attachment with stipe. } \\
\text { Stipe } 1.5-2 \mathrm{~cm} \text { long, pale yellow, } \\
\text { smooth, leathery, firm, thick, } \\
\text { full, stout, eccentric. Gills } \\
\text { decurrent, pale yellow, narrow } \\
\text { close. Spores } 6.25-8.5 \mathrm{X} 3-4 \\
\mu \mathrm{m} \text {, ellipsoid, smooth, hyaline, } \\
\text { non-amyloid. Spore print } \\
\text { whitish. Flesh yellowish, firm. }\end{array}$ & $25 / 8 / 12$ & DDUNPL249 \\
\hline $\begin{array}{l}\text { P. ostreatus } \\
\text { (Jacq: Fries) }\end{array}$ & Piprauli & $\begin{array}{l}\text { Mangifera } \\
\text { indica }\end{array}$ & $\begin{array}{l}\text { Pileus 3-10 } \mathrm{cm} \text {, convex, kidney } \\
\text { shaped to fan shaped, greasy } \\
\text { smooth, pale brown in colour, } \\
\text { margin inrolled. Stipe } \\
\text { rudimentary, eccentric, thick, } \\
\text { stuffed, whitish. Gills close, } \\
\text { parallel, running down the stem. } \\
\text { Spores } 7-8 \text { X } 2.5-3 \mu \mathrm{m} \text {, smooth, } \\
\text { cylindrical. Spore print whitish. }\end{array}$ & $8 / 7 / 12$ & DDUNPL250 \\
\hline
\end{tabular}




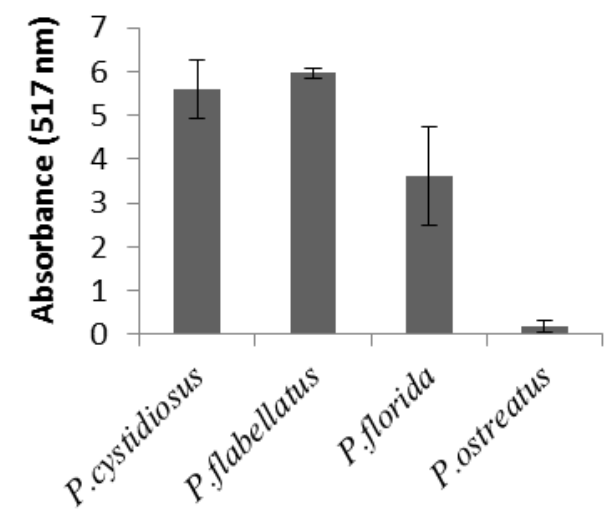

Fig. 1 - DPPH Radical scavenging activity $\left(E_{50}\right)$ of four oyster mushrooms. Each value is the mean of three replicate determination \pm standard deviation $(\mathrm{p}<0.05)$

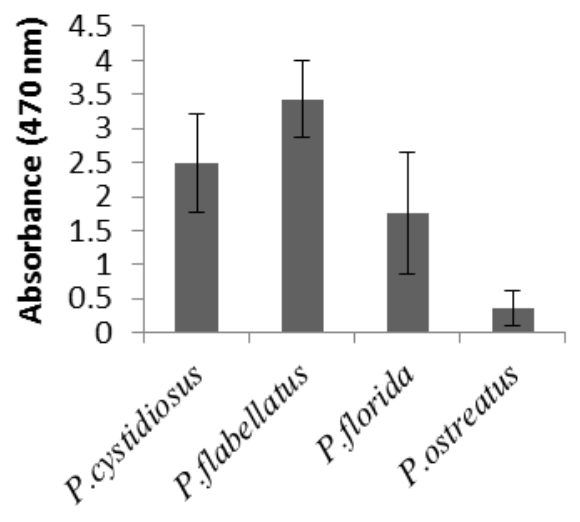

Fig. $3-\mathrm{H}_{2} \mathrm{O}_{2}$ Scavenging assay $\left(\mathrm{EC}_{50}\right)$ of four oyster mushrooms. Each value is the mean of three replicate determination \pm standard deviation $(\mathrm{p}<0.05)$.

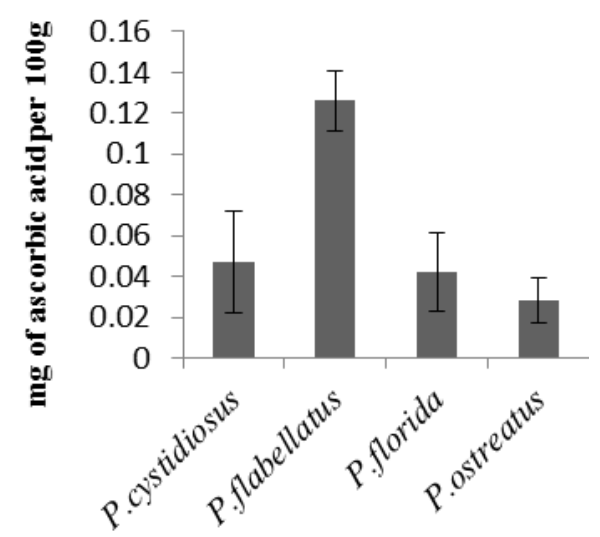

Fig. 5 - Lycopene content $(\mu \mathrm{g} / \mathrm{mg})$ from aqueous extract of four oyster mushroom. Each value is the mean of three replicate determination \pm standard

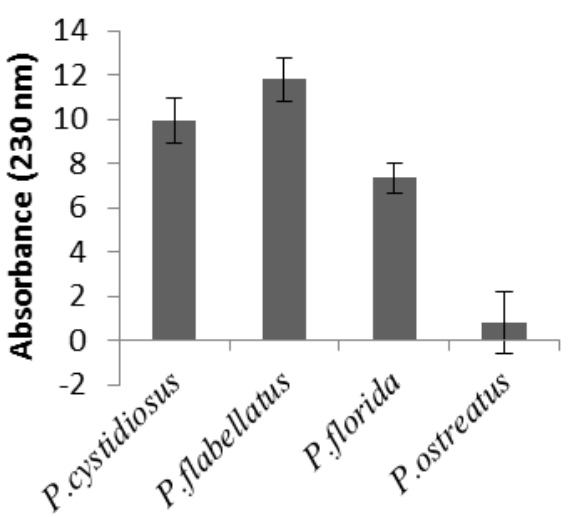

Fig. 2 - $\beta$-carotene bleaching assay $\left(\mathrm{EC}_{50}\right)$ of four oyster mushrooms. Each value is the mean of three replicate determination \pm standard deviation $(\mathrm{p}<0.05)$

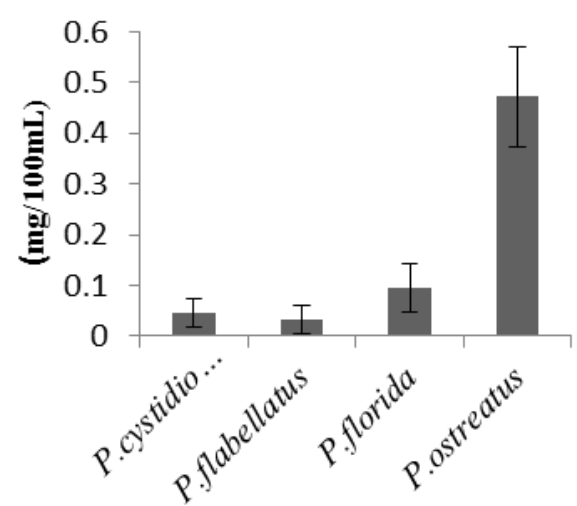

Fig. 4 - $\beta$-carotene content $(\mu \mathrm{g} / \mathrm{mg})$ from aqueous extract of four oyster mushroom. Each value is the mean of three replicate determination \pm standard deviation $(p<0.05)$.

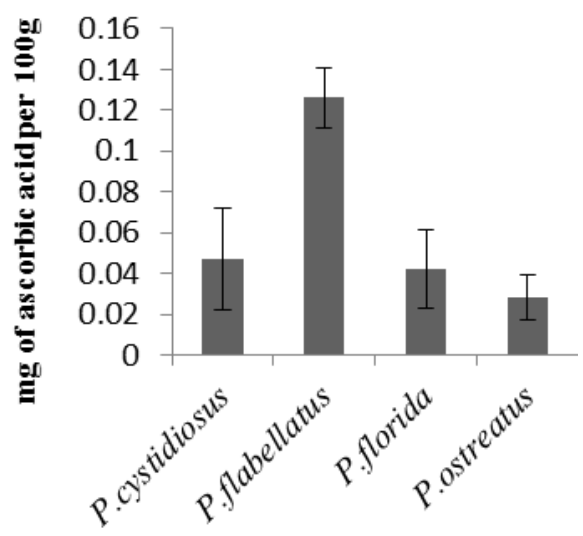

Fig. 6 - Ascorbic acid content (mg/g) from aqueous extract of four oyster mushroom. Each value is the mean of three replicate determination \pm standard deviation $(\mathrm{p}<0.05)$.

\section{Nutritional property of collected oyster mushrooms}

Table 2 represents nutrients value viz., protein, carbohydrate, lipid, moisture, ash and fibre of tested oyster macrofungi. In present study, higher protein content was observed in $P$. ostreatus $(43.70 \pm 1.77 \%)$ while lowest in $P$. flabellatus $(40.27 \pm 0.36 \%)$. Carbohydrate ranged between $33.12 \pm 1.66-42.69 \pm 1.75 \%$. Highest carbohydrate was recorded in P. flabellatus $(42.69 \pm 1.75 \%)$ 


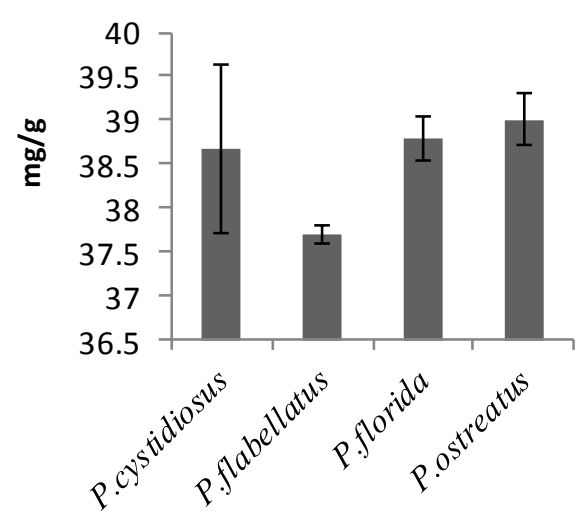

Fig. 7 - Total phenolic content $(\mathrm{mg} / \mathrm{g})$ of oyster mushrooms (Aqueous extract). Each value is the mean of three replicate determination \pm standard deviation $(\mathrm{p}<0.05)$.

Table 2 Biochemical assay of collected oyster mushrooms (\%)

\begin{tabular}{lcccccc}
\hline Macrofungi & $\begin{array}{c}\text { Protein } \\
(\boldsymbol{\%})\end{array}$ & $\begin{array}{c}\text { Carbohydrate } \\
(\boldsymbol{\%})\end{array}$ & Lipid (\%) & $\begin{array}{c}\text { Moisture } \\
(\boldsymbol{\%})\end{array}$ & Ash (\%) & Fibre (\%) \\
\hline & & & & & & \\
P.cystidiosus & $41.11 \pm 1.69$ & $40.49 \pm 0.67$ & $0.42 \pm 0.05$ & $85.18 \pm 0.93$ & $6.65 \pm 0.78$ & $17.55 \pm 1.65$ \\
$\boldsymbol{P . f l a b e l l a t u s}$ & $40.27 \pm 0.36$ & $42.69 \pm 1.75$ & $0.65 \pm 0.08$ & $84.90 \pm 1.12$ & $5.72 \pm 0.79$ & $13.57 \pm 0.55$ \\
$\boldsymbol{P}$. florida & $42.50 \pm 0.29$ & $33.12 \pm 1.66$ & $0.59 \pm 0.03$ & $83.70 \pm 1.75$ & $6.44 \pm 1.12$ & $11.42 \pm 0.91$ \\
$\boldsymbol{P . o s t r e a t u s}$ & $43.70 \pm 1.77$ & $35.00 \pm 0.75$ & $0.57 \pm 0.11$ & $80.29 \pm 1.26$ & $7.69 \pm 0.72$ & $18.08 \pm 1.23$ \\
\hline
\end{tabular}

Values are mean of three replicates \pm standard error

followed by $P$. cystidiosus $(40.49 \pm 0.67 \%)$, P. ostreatus $(35.00 \pm 0.75 \%)$ and P. florida (33.12 $\pm 1.66 \%)$. Lipid content varies from $0.42 \pm 0.05-0.65 \pm 0.08 \%$, lowest in P.cystidiosus and highest in P. flabellatus. The highest moisture content was observed in $P$. cystidiosus $(85.18 \pm 0.93 \%)$ and lowest in P.ostreatus $(80.29 \pm 1.26 \%)$. Ash content of tested mushrooms was recorded between 5.72 $\pm 0.79-7.69 \pm 0.72 \%$. Highest ash content was observed in P. ostreatus $(7.69 \pm 0.72 \%)$ while lowest in P. flabellatus $(5.72 \pm 0.79 \%)$. Fibre content of oyster mushrooms tested ranged between $11.42 \pm 0.91-18.08 \pm 1.23 \%$. Highest fibre was observed in P.ostreatus $(18.08 \pm 1.23 \%)$ while lowest in P. florida $(11.42 \pm 0.91 \%)$.

\section{Discussion}

All collected oyster mushrooms differ in their spore size and morphology (Table 1). They were found in saprotrophic association with different trees except $P$. flabellatus which was growing on decaying wood. This shows that oyster mushrooms are host dependent and grow on specific host (Alam et al. 2009, Musieba et al. 2011, Dhancholia 2013).

Free radical scavenging is a mechanism which inhibits lipid oxidation and is use to estimate antioxidant activity (Umamaheshwari \& Chatterjee 2008). In present study, the radical scavenging activity of mushroom extracts were tested against the DPPH activity, $\beta$-carotene-linoleic acid assay and hydrogen peroxide reducing power activity.

DPPH is a stable free radical with good absorption at $517 \mathrm{~nm}$, it is use to study radical scavenging activity of extracts. When antioxidant donate proton to these radicals then absorption of samples decreases. Radical scavenging activity is measured by decrease in absorption of samples (Srivastava et al. 2006). All tested extract at different concentrations in present study showed good radical scavenging activity. Earlier studies with Pleurotus species extracts showed $\mathrm{EC}_{50}$ value for DPPH scavenging activity $11.56 \mathrm{mg} / \mathrm{ml}$ for P. ostreatus (Chirinang \& Intarapichet 2009). The variation may be attributed to difference in the concentration in the antioxidant compounds because of the solvent used for extraction. Sample with more phenolic content exhibited more antioxidant activity (Rajasekaran \& Kalaimagal 2011). In $\beta$-carotene-linoleic assay free radicals of linoleic acid 
adds up with radicals of carotenoids and results in its high antioxidant property. Different antioxidants of mushrooms hinder with the $\beta$-carotene bleaching. They neutralises the linoleate free radicals and other radicals of the system (Adebayo et al. 2014). Hydrogen peroxide is a common metabolite generated in the body during superoxide reduction. In excess $\mathrm{H}_{2} \mathrm{O}_{2}$ is cytotoxic as it is easily converted to harmful hydroxyl radical (Kuppusamy et al. 2009). It has been found that antioxidant property of mushrooms is generally due to the presence of polyphenols in them. $\mathrm{H}_{2} \mathrm{O}_{2}$ Scavenging activity (Fig. 3) was also found to present in good quantity which correlates with the finding of Vamanu (2012) for extract of A.bisporus (J. E. Lange) Imbach.

In present study $\beta$-carotene and lycopene was also found but in small concentration. Both act as a powerful antioxidant. $\beta$-carotene is a member of the carotenoid family, which are highly pigmented (red, orange, yellow), fat-soluble compounds naturally present in many fruits, grains, oils, and vegetables. Among the naturally occurring carotenoids that can be converted to vitamin A in the human body, so-called 'provitamin A carotenoids', $\beta$-carotene is the most abundant and most efficient one found in foods. Lycopene contain 11 conjugated and 2 non-conjugated double bond which results in its high singlet oxygen quenching ability (Pal et al. 2010). They both help to reduce the risk of cardiovascular diseases and prostate cancer. Both are found in very small concentration in tested mushroom samples.

Phenols are important component of plants and mushrooms. It has been found to be the most important component imparting antioxidant quality of mushrooms. They contribute directly to antioxidant effect of system as they have capacity to eliminate free radicals due to presence of hydroxyl group. They are important for plants, vegetables and mushrooms (Ferreira et al. 2007). The phenolic concentration of samples analysed in present study were same than those reported by Chirinang \& Intarapichet (2009) for P.ostreatus and P. sajor caju.

Nutrition is one of the main concerns of all of the societies of the world. Food supply should be both an economic and ecological subject. Health and nutrition involve balanced and sufficient functional food components (Çağlarirmak 2011). Nutritional value of mushroom depends largely on the chemical composition of the compost on which they are growing (Goyal et al. 2006). Mushrooms are considered to be healthy food because of their high and qualitatively good protein content, low fat and cholesterol content, minerals and vitamins. Protein is an important constituent of dry matter of mushrooms of high quality. The protein contents of mushrooms are affected by a number of factors, namely the type of mushrooms, the stage of development, the part sampled, level of nitrogen available and the location (Longvah \& Deosthale 1998). The carbohydrate content of mushroom represents the bulk of fruiting bodies accounting for 50 to $65 \%$ on dry weight basis. Free sugars amounts to about $11 \%$ (Thatoi \& Singdevsachan 2014). Adejumo et al. (2015) reported 33.57 and $37.64 \%$ carbohydrate in the fruiting bodies of $P$. ostreatus and $P$. pulmonarius respectively. Alam et al. (2008) determine the carbohydrate content of $P$. florida, $P$. ostreatus, $P$. sajor caju and found it as 42.83, 37.8 and $39.82 \mathrm{~g} / 100 \mathrm{~g}$ respectively. Dundar et al. (2008) studied several species of oyster mushroom and reported that carbohydrate of P. eryngii, P. ostreatus and $P$. sajor-caju were $39.85,37.87$ and $37.72 \mathrm{~g} / 100 \mathrm{~g}$ respectively. Similar results were also recorded in present work for carbohydrate concentration in different oyster mushroom evaluated.

In mushrooms (wild and cultivated both), the fat content is very low (4-6\%) as compared to proteins and carbohydrates (Thatoi \& Singdevsachan 2014). Mushrooms contain all the main classes of the lipid compounds including free fatty acids, mono-, di- and triglycerides, sterols, sterol esters and phospholipids. Mushrooms are rich in linolenic acid which is an essential fatty acid (Nile \& Park 2014) but are more dominated by unsaturated fatty acids (Longvah \& Deosthale 1998). Due to the low fat and oil content, they are recommended as good source of food supplement for patients with cardiac problems or at risk with lipid-induced disorders (Manimozhi \& Kaviyarasan 2013). In present work lipid content varies from $0.42 \pm 0.05-0.65 \pm 0.08 \%$ showing the similarities with the other previous findings. Alam et al. (2008) determine the lipid content of four mushroom viz. P. florida, P. ostreatus and P. sajor caju, and found it to be $0.54,0.68,0.57$ $\mathrm{g} / 100 \mathrm{~g}$. Khan et al. (2013) reported lipid content of Pleurotus (flabellatus) djamor (R-22) cultivated on sawdust of different wood and mention that lipid content ranged from $0.11-0.80 \%$. 
Gbolagade et al. (2006) stated that young fruit bodies of Pleurotus florida contains $0.9 \%$ of lipid while mature fruit bodies contain $1.2 \%$ of lipid. Lipid content of mushroom depends upon the type of substratum on which they are growing and time of harvesting.

Mushrooms generally have high moisture content which accounts for their short shelf life as they deteriorate easily after harvest if preservative measures are not employed (Adedayo \& Rachel 2011). Fresh mushroom contains about $90 \%$ moisture and $10 \%$ dry matter and dry mushroom contains $90 \%$ dry matter and 10\% moisture (Johnsy \& Davidson 2011). Goyal et al. (2006) reported that $P$. sajor caju contains $89.58 \%$ of moisture. Alam et al. 2008 estimated the moisture content of different species of Pleurotus and reported that $P$. ostreatus contains highest moisture $(86.0 \%)$ followed by $P$. sajor caju $(87.0 \%)$ and P. florida (87.5\%). In present work, the moisture content of different oyster mushroom was found to be in range of $80.29 \pm 1.26 \%$ to $85.18 \pm 0.93 \%$ which completely shows the similarity with former works done.

The main constituents in the mushroom ash are $\mathrm{K}$ and $\mathrm{P}$ (totaly 60\%) (Colak et al. 2009). In present work done ash content was found to be the range of $5.72 \pm 0.79-7.69 \pm 0.72 \%$ correlating the present findings with another works completely. Adejumo et al. (2015) determined the ash content of two oyster mushrooms viz., P. ostreatus (5.65\%) and P. pulmonarius (7.95\%). Dundar et al. (2008) estimated the ash content of 3 species of Pleurotus viz., P. eryngii, P. ostreatus and P. sajor caju and found it to be $4.89,4.78$ and $5.84 \%$ respectively, but in another work carried out by Goyal et al. (2006) for P. sajor caju ash content was observed to be $7.46 \%$.

Mushroom contains good quality fibre. It helps in lowering the cholesterol. Fresh mushrooms contain both soluble and insoluble fibre. The soluble fibre is mainly $\beta$-glucans and chitosans, which are components of the cell walls (Kakon et al. 2012). Fibre content of oyster mushrooms tested ranged between 11.42 $\pm 0.91-18.08 \pm 1.23 \%$. Highest fibre content was found in $P$. ostreatus which was same as given by Jonathan et al. (2012). Oyetayo et al. (2007) analyzed the nutritional property of different parts (pileus and stipe) of cultivated and wild strains of Pleurotus sajor caju and observed that wild sample contains higher amount of fibre than the cultivated strain. Stalk of both strains viz. cultivated and wild sp., contains higher fibre $(16.24 \%$ and $26.14 \%$ respectively). Goyal et al. (2006) in another experiment stated that $P$. sajor caju contains $12.13 \%$ fibre.

\section{Conclusion}

Mushrooms are rich reservoir of nutrients and also possess various medicinal prospects. Mushrooms either wild or cultivated are rich sources of protein and fibres while are low in lipid and calorie. Hence they can be recommended as good diet for peoples having various health problems. Mushroom also contain high phenol content and shows good antioxidant property. Various species of Pleurotus possess high bioactive compounds which imparts for its good antioxidant property. Pleurotus are also rich in nutrients and hence it can be included in diet to obtain nutrients and also to protect the human body against various types of free radicals generated during the process of oxidation which in turn protect the body from various diseases.

\section{Acknowledgements}

The authors wish to thank Head, Department of Botany DDU Gorakhpur University, Gorakhpur for providing necessary Lab. facilities.

\section{References}

Adebayo EA, Oloke JK, Aina DA, Bora TC. 2014 - Antioxidant and nutritional importance of some Pleurotus species. Journal of Microbiology Biotechnology and Food Sciences 3, 289294.

Adedayo, Rachel M. 2011 - Proximate analysis on four edible mushrooms. J. Appl. Sci. Environ. Manage 15(1), 9-11. 
Adejumo TO, Coker ME, Akinmoladun VO. 2015 - Identification and evaluation of nutritional status of some edible and medicinal mushrooms in Akoko Area, Ondo state, Nigeria. Int J. of Current Microbiology and App. Sci 4(4), 1011-1028.

Ahmed M, Abdullah N, Ahmed KU, Bhuyan NHMB. 2013 - Yield and nutritional composition of oyster mushroom strains newly introduced in Bangladesh. Pesq. Agropec. Bras. Brasilia 48, 197-202.

Alam N, Amin R, Khan A, Ara I, Shim MJ, Lee MW, Lee TS. 2008 - Nutritional analysis of cultivated mushrooms in Bangladesh - Pleurotus ostreatus, Pleurotus sajor-caju, Pleurotus florida and Calocybe indica. Mycobiology 36(4), 228-232.

Alam N, Shim MJ, Lee MW, Shin PG, Yoo YB and Lee TS. 2009 - Phylogenetic relationship in different commercial strains of Pleurotus nebrodensis based on ITS sequence and RAPD. Mycobiology 37(3), 183-188.

Arbaayah HH, Umi Kalsom Y. 2013 - Antioxidant properties in oyster mushrooms (Pleurotus spp.) and split gill mushroom (Schizophyllum commune) ethanolic extract. Mycosphere 4(4), 661-673.

Atri NS, Sharma SK, Joshi R, Gulati A, Gulati A. 2012 - Amino acid composition of five wild Pleurotus species chosen from North West India. European Journal of Biological Sciences 4, 31-34.

Barros L, Falcâo S, Baptista P, Freire C, Vilas-Boas M, Ferreira Isabel CFR. 2008 - Antioxidant activity of Agaricus sp. mushrooms by chemical, biochemical and electrochemical assay. Food Chemistry 111, 61-66.

Chang Heng-Yuan, Ho Yu-Ling, Sheu Ming-Jyh, Lin Yaw-Huei, Tseng Mu-Chuan, Wu ShengHua, Huang Guan-Jhong, Chang Yuan-Shiun 2007 - Antioxidant and free radical scavenging activity of Phellinus merrilli extracts. Botanical Studies 48, 407-417.

Cheung LM, Peter CK. 2005 - Mushroom extracts with antioxidant activity against lipid peroxidation. Food Chemistry 89, 403-409.

Çağlarirmak N. 2011 - Edible mushrooms: an alternative food item. Proceedings of the $7^{\text {th }}$ International Conference on Mushroom Biology and Mushroom Products. pp 548-554.

Chirinang P, Intarapichet Konak-Oron 2009 - Aminoacids and antioxidants properties of oyster mushrooms Pleurotus ostreatus and Pleurotus sajor-caju. Science Asia 35, 326-331.

Colak A, Faiz Ö, Sesli E.2009 - Nutritional composition of some wild edible mushrooms. Turkish Journal of Biochemistry 34(1), 25-31.

Dhancholia S. 2013 - Pleurotus himalayaensis Dhancholia Sp.nov. a highly delicious edible mushroom from dry temperate cold desert zone of Lahoul valley in Himachal Pradesh (India). American-Eurasian J. Agric. \& Environ. Sci 13 (1), 44-49.

Dundar A, Acay H, Yildiz A. 2008 - Yield performances and nutritional contents of three oyster mushroom species cultivated on wheat stalk. African Journal of Biotechnology 7(19), 3497-3501.

Ferreira ICFR, Baptista P, Vilas-Boas M, Barros 2007 - Free radical scavenging capacity and reducing power of wild edible mushrooms from North East Portugal: Individual cap and stipe activity. Food Chemistry 100, 1511-1516.

Folch J, Lees M, Sloane-Stanely GH. 1957 - A simple method for the isolation and purification of total lipids from animal tissues. J. Biol. Chem 226(1), 497-509.

Gbolagade J, Ajayi A, Oku I, Wankasi D. 2006 - Nutritive value of common wild edible mushrooms from Southern Nigeria. Global Journal of Biotechnology and Biochemistry $1(1), 16-21$.

Goyal R, Grewal RB, Goyal RK. 2006 - Nutritional attributes of Agaricus bisporus and Pleurotus sajor caju mushrooms. Nutrition and Health 18, 179-184.

Johnsy I, Okon J. 2013 - Antidiabetic effect of Pleurotus ostreatus (Jacq.ex.Fr.) Kunm. Mushroom on Alloxan induced Diabetic Rats. Indian Journal of Pharmaceutical and Biological Research 1, 31-36. 
Johnsy G, Davidson SS. 2011 - Nutritive value of edible wild mushrooms collected from the Western ghats of Kanyakumari. Botany Research International 4, 69-74.

Jonathan SG, Okon CB, Oyelakin AO, Oluranti OO. 2012 - Nutritional values of oyster mushroom (Pleurotus ostreatus) (Jacq. Fr.) Kumm. cultivated on different agricultural wastes. Nature and Science 10(9), 186-191.

Kakon AJ, Choudhury Md. Bazlul K, Saha S. 2012 - Mushroom is an ideal food supplement. J. Dhaka National Med. Coll. Hos 18 (1), 58-62.

Khan NA, Ajmal M, Nicklin J, Aslam S, Ali MA. 2013 - Nutritional value of Pleurotus (flabellatus) djmor (R-22) cultivated on sawdusts of different woods. Pak. J. Bot 45, 11051108.

Kong Won-Sik 2004 - Description of commercially important Pleurotus species. Mushroom Grower's handbook 1(II) Oyster Mushroom, Chapter 4. http://www.alohamedicinals.com/book1/chapter-4.pdf (assessed on 10.06.2014).

Kuppusamy UR, Chong YL, Mahmood AA, Indran M, Abdullah N, Vikineswary S. 2009 Lentinus edodes (Shittake) mushroom extract protects against hydrogen peroxide induced cytotoxicity in peripheral blood mononuclear cells. Indian Journal of Biochemistry and Biophysics 46, 161-165.

Loganathan Jagadish K, Gunasundari D, Hemalatha M, Shenbhagaraman R, Kaviyarasan V. 2010 Antioxidant and phytochemical potential of wild edible mushroom Termitomyces reticulates: Individual cap and stipe collected from South Eastern part of India. International Journal of Pharmaceutical Science and Research 1, 62-72.

Longvah T, Deosthale YG. 1998 - Compositional and nutritional studies on edible wild mushroom from Northeast India. Food Chemistry 63(3), 331-334.

Lowry OH, Rosenbrough NJ, Farr AL, Randall RJ. 1951 - Protein measurement with the folin phenol reagent. J Biol Chem 193, 265-275.

Manimozhi M, Kaviyarasan V. 2013 - Nutritional composition and antibacterial activity of indigenous edible mushroom Agaricus heterocystis. International Journal of Advanced Biotechnology and Research 4(1), 78-84.

Mau JL, Lin HC, Song SF. 2002 - Antioxidant properties of several specialty mushrooms. Food. Res. Intl 35, 519-526.

Musieba Fredrick, Okoth Sheila and Mibey Richard K. 2011 - First record of the occurrence of Pleurotus citrinopileatus Singer on new hosts in Kenya. Agriculture and Biology Journal of North America 2(9), 1304-1309.

Nile Shivraj Hariram, Park Se Won 2014 - Total, soluble and insoluble dietary fibre contents of wild growing edible mushrooms. Czech J. Food Sci 32(3), 302-307.

Orsine Vinhal Costa J, Novaes MaR Cavalho Garbi, Ramirez Asquieri E. 2012 - Nutritional value of Agaricus sylvaticus: mushroom grown in Brazil. Nutricion Hospitalaria 27, 449-455.

Oyetayo FL, Akindahunsi AA, Oyetayo VO. 2007 - Chemical profile and amino acids composition of edible mushrooms Pleurotus sajor caju. Nutrition and Health 18, 383-389.

Pal Jaita, Ganguly Sourav, Tahsin KS, Acharya K. 2010 - In vitro free radical scavenging activity of wild edible mushrooms, Pleurotus squarrosulus (Mont.) Singer. Indian Journal of Experimental Biology 47, 1210-1218.

Patel Yashvant, Naraian Ram, Singh VK. 2012 - Medicinal Properties of Pleurotus species (oyster mushroom): A review. World Journal of Fungal and Plant Biology 3(1), 1-12.

Pearson D. 1976 - The chemical analysis of food. $6^{\text {th }}$ edition. (Chemical publishing company. New York), 169-172.

Rajasekaran M, Kalaimagal C. 2011 - In vitro antioxidant activity of ethanolic extract of a medicinal mushroom, Ganoderma lucidum. Journal of Pharmaceutical Sciences and Research 3, 1427-1433.

Roy Amit, Prasad Pushpa 2013 - Therapeutic Potential of Pleurotus ostreatus: A Review. Research J. Pharm. and Tech 6(9), 937-940. 
Srivastava Anup, Harish SP, Shivanandappa T. 2006 - Antioxidant activity of the roots of Decalepis hamiltonii (Wigh \& Arn.). LWT 39, 1059-1065.

Thatoi H, Singdevsachan SK. 2014 - Diversity, nutritional composition and medicinal potential of Indian mushrooms: A review. African Journal of Biotechnology 13(4), 523-545.

Thimmaiah SK. 1999 - Carbohydrate in standard methods of biochemical analysis. Kalyani Publishers. New Delhi. ISBN 81-7663-067-5 pg49-76.

Turkoglu A, Kivrak I, Mercan N, Duru M, Gezer K, Turkoglu H. 2006 - Antioxidant and antimicrobial activity of Morchella conica Pers. African Journal of Biotechnology 5, 11461150.

Umamaheshwari M, Chatterjee TK. 2008 - In vitro antioxidant activities of the fractions of Coccinia grandis L. Leaf extract. Afr J Tradit Complement Altern Med 5(1), 61-73

Vamanu E. 2012 - Determination of antioxidant and antimicrobial properties of Agaricus bisporus from Romanian market. Ovidius University Annals of Chemistry 23, 47-52. 